\title{
The Baltic Dry Index and performance excellence in a crisis environment
}

\author{
Elza Jurun ${ }^{1}$, Nada Ratković, ${ }^{1, *}$ and Frano Moro ${ }^{2}$ \\ ${ }^{1}$ Faculty of Economics Split, University of Split \\ Cvite Fiskovića 5, 21000 Split \\ E-mail: 〈elza@efst.hr, nada.ratkovic1@gmail.com〉 \\ ${ }^{2}$ Moro E3 Moro j.d.o.o. \\ Gala 141, 21238 Otok Dalmatinski \\ E-mail: 〈frano.moro@gmail.com〉
}

\begin{abstract}
This paper focuses on an approach to analyzing the relationship between the Baltic Dry Index (BDI) as the main indicator of the cyclical nature of the maritime market and the performance excellence of the representative shipping companies. Results have shown that there is a strong positive correlation between average annual BDI values and performance excellence indicators measured by the traditional adjusted Altman Z-score as well as the recent indicator, the Bex Index. BDI as the most comprehensive indicator of global demand for commodities and raw materials is also analyzed as a supply and demand signal on the stock market. The aim was to test the hypothesis that BDI also functions as a signal that promptly responds to crisis effects. The methodological procedure has been carried out using a real database spanning from 1985 to 2013 where the results have confirmed the hypothesis.
\end{abstract}

Key words: Baltic Dry Index, performance excellence, Bex Index, adjusted Altman Z-score, maritime market, shipping companies excellence

Received: September 20, 2014; accepted: May 18, 2015; available online: October 31, 2015

DOI: $10.17535 /$ crorr.2015.0026

\section{Introduction}

As the world stock market oscillates in an ever-tightening trading range, investors around the world are trying to read stock tickers to determine what will happen next. The Baltic Dry Index, as the most comprehensive indicator of global demand for commodities and raw materials, will be analyzed in this paper as a supply and demand signal on the stock market. Therefore, finding a new approach to analyzing the relationship between BDI and the performance excellent of representative shipping companies was deemed important. Besides

${ }^{*}$ Corresponding author. 
the traditional indicator, the adjusted Altman Z-score of business performance will be further measured by a recent performance indicator - the Bex Index. The Bex Index has so far been applied solely to assessing production enterprises. In this paper, the Bex Index will be applied to the same data of shipping companies, to which the Z-score indicator was applied. If the adjusted Altman Z-score, the Bex Index and the BDI show the same trends in business performance for the selected sample of maritime companies, it could possibly lead to at least two very useful scientific conclusions. First, the contemporary indicator of business excellence - the Bex Index, just like the traditional Z-score, can be used for measuring the performance excellence of maritime companies, as used to be done by the Bex Index for production enterprises. Secondly, if the BDI increases in the period when both mentioned indicators indicate higher business excellence, and if its decrease follows a reduction of business success in the observed companies, the BDI can be used, among other things, as a supply and demand signal on the stock market. It is commonly known that the BDI is this very signal in a no crisis period, hence this paper aims to test the hypothesis that BDI as a signal also responds promptly to the effects of a crisis. Specifically, a high correlation between short-term (quarterly) average BDI values and a company's business excellence results indicates the possibility of a buying or selling signal for certain shares. This signal is even more indicative given that it occurs before the quarterly accounting reports for maritime companies.

This paper is organized as follows. After the introduction, the second part of the paper presents a theoretical background along with the history and meaning of the BDI Index, the performance excellence and methods used to measure it. The topic of the third section is the case study incorporating an appropriate methodology applied to a database on a chosen sample of maritime companies. The analysis procedure is comprehensive using the complete database on performance excellence indicators from accounting reports of the chosen maritime companies. The time horizons of the comparative BDI analysis are the years 1985 and 2013. The final section is dedicated to providing a conclusion.

\section{Theoretical background}

The BDI is a leading indicator providing clear insight into global demand for commodities and raw materials. The fact that the BDI focuses on raw materials is important given that demand for raw materials provides a glimpse into the future. Producers buy raw materials when they want to build an increased number of finished goods and infrastructure. They cease buying raw materials when reaching excess inventory or halting infrastructure projects. More importantly, the index measures demand for shipping capacity against the 
supply of dry bulk carriers, thus providing a good approximation of global economic activity [11]. The BDI continues the established time series of the Baltic Freight Index (BFI), which was introduced in 1985. The BDI is not the only dry bulk index available; however, it seems to be the most comprehensive [18].

The Baltic Exchange has a long history dating back to 1744, when it was first established through casual conversations between merchants and ship captains at the Virginia and Baltick Coffee House in Threadneedle Street, London [5]. In 1985, the Baltic Exchange launched the BDI as a general indicator of shipment rates for dry bulk cargoes. The BDI provides an assessment of the price of moving major raw materials by sea. Taking in account 26 major shipping routes measured on a time charter and voyage basis, the index covers: (1) Capemax (10 percent of the global fleet), ships that can carry 100,000 + dead weight tons of cargo and are too big to pass through the Panama Canal; (2) Panamax (19 percent of the global fleet), ships that can carry 60,000-80,000 dead weight tons of cargo and can barely fit through the Panama Canal; (3) Handymax, and (4) Supramax (37 percent of the global fleet), ships that can carry 45,000-59,000 dead weight tons of cargo; (5) Handysize (34 percent of the global fleet), ships that can carry 15,000-35,000 dead weight tons of cargo [18].

The BDI is also a compelling indicator as a simple, real-time indicator that is difficult to manipulate. Some economic indicators, like unemployment rates, inflation indexes and oil prices, can be difficult to interpret because they can be manipulated or influenced by governments, speculators and other key players [13]. The BDI, on the other hand, is difficult to manipulate as it is driven by clear forces of supply and demand.

The BDI is affected by the supply of ships available for shipping materials around the globe. This supply is difficult to manipulate or distort, as it takes years to build a new ship that could be put into service to increase supply, and it would cost far too much to leave ships empty in an attempt to decrease supply.

The index is also affected by demand from commodity buyers who need raw goods for production. Demand is difficult to manipulate or distort, as it is calculated solely on the basis of those who have placed orders for shipping raw goods. Going back thirty years ago, let's look and analyze the basic trends of BDI movements in the period before the great economic crisis. Introduced in 1985, the BDI first and foremost is a measure of global shipping rates of dry bulk goods, mostly consisting of vital raw materials used in the creation of other products. However, it is also a measure of demand for the said materials in comparison to previous months and years. 


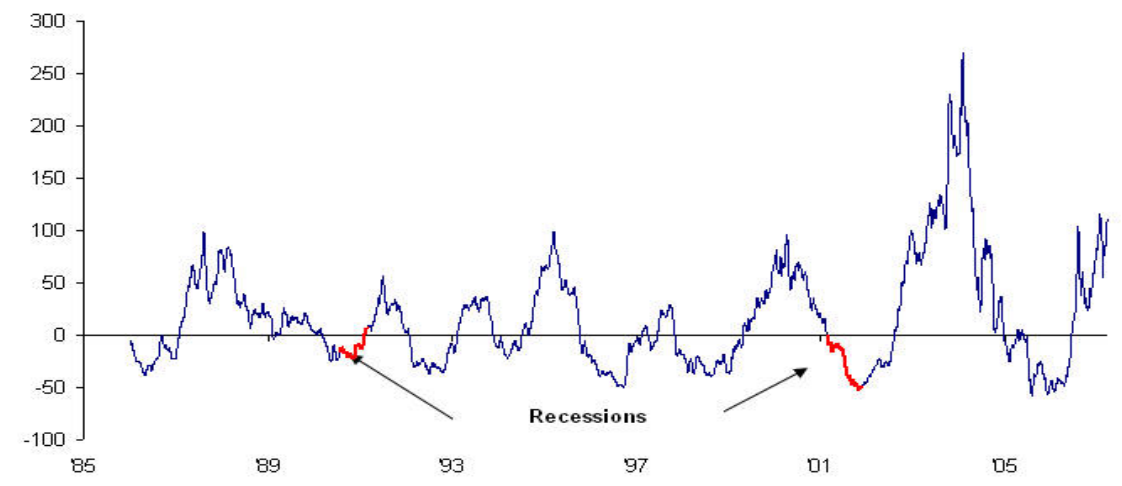

Figure 1: BDI movement from 1985 to 2013

In late 1986, for instance, the BDI fell to its lowest level on record, then, began its slow crawl toward a moderate recovery, just before the Black Monday crash of 1987[19]. From 2001 to 2002, a similar sharp collapse in the BDI preceded a progressive drop in the Dow of around 4000 points, ending in a highly suspect (Fed engineered) illegitimate recovery.

In 2008, the index fell to near record lows once again just before the derivatives and credit crisis hit stocks full force. To imply that the BDI is not a useful measure of future economic trends seems like an astonishingly ignorant proposition when one examines its very predictable behavior just before major financial downturns. On 20 May 2008, the index reached its record high level since its introduction in 1985, reaching 11,793 points. Half a year later, on 5 December 2008, the index had dropped by $94 \%$, to 663 points, the lowest since 1986, though by 4 February 2009 it had recovered a little lost ground, back to 1,316 .

These low rates moved dangerously close to the combined operating costs of vessels, fuel, and crews. By the end of 2008, shipping times had been already increased by reduced speeds to save fuel consumption, but lack of credit meant the reduction of letters of credit, historically required to load cargoes for departure at ports.

Debt load of future ship construction was also a problem for shipping companies, with several major bankruptcies and implications for shipyards. This, combined with the collapsing price of raw commodities created a perfect storm for the world's marine commerce. During 2009, the index recovered as high as 4661, but then bottomed out at 1043 in February, 2011, after continued deliveries of new ships and flooding in Australia. Though rebounding to 2000 on 7 October, by 3 February 2012, the index made a new multi-decade low of 647 on a continued glut of dry bulk carriers and decreases in orders of iron and coal. 


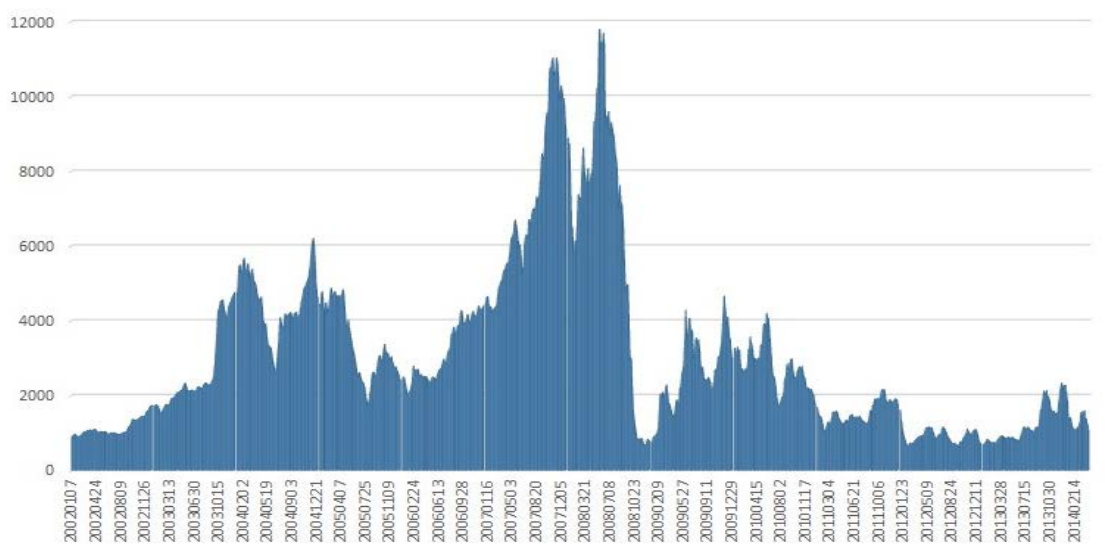

Figure 2: BDI movement from 1985 to 2014

The above graph underlines that the BDI has been very volatile in recent years, particularly between 2005 and 2009 when it behaved as a bubble. The main driver of this surge was linked to commodity prices, particularly oil. The index then plummeted back to historical levels and has remained weak in spite of a recovery in global trade. A main reason is that many ships were ordered during the "bubble years" and have entered the market, providing capacity growth above demand growth [15]. In recent days, BDI movement analysis leads to the conclusion that BDI is collapsing, reaching some of its lowest value in the history of monitoring. Though rebounding to 2000 on 7 October, by 3 February 2012, the index reached a new multi-decade low of 647 on a continued glut of dry bulk carriers and decreases in orders of iron and coal [17].

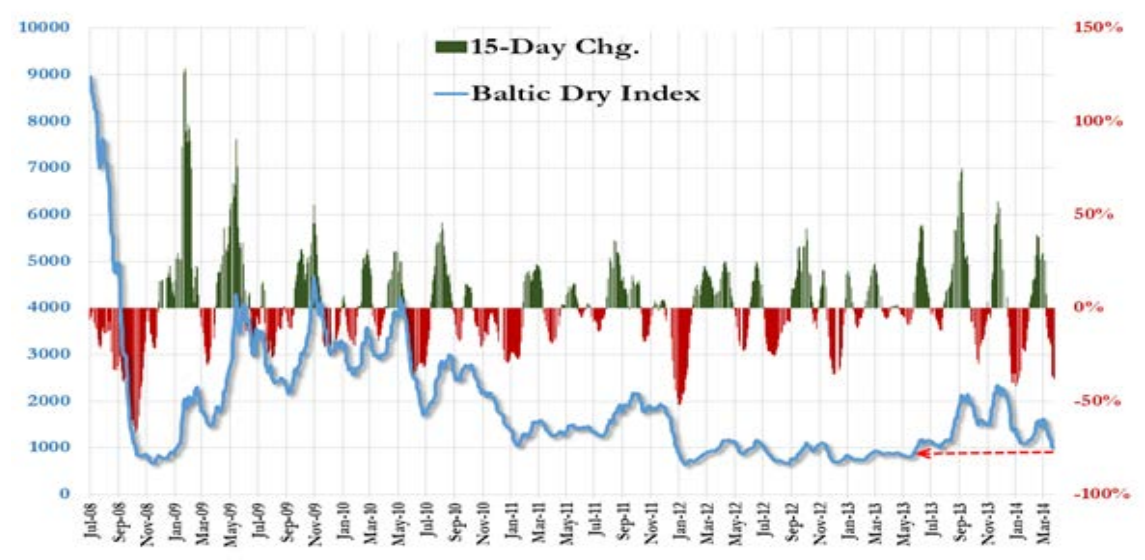

Figure 3: BDI movement from July 2008 to March 2014 
The figure above vividly and graphically represents that something extreme is occurring in the cost of shipping dry bulk around the world. The year 2014 is witnessed the biggest drop in price (a typical seasonal pattern) at the start the year since records began [11].

\section{Performance excellence methodology}

Performance excellence is defined by different authors in different ways in accordance with target and purposes. For the purpose of this research, the authors estimated maritime company performance excellence using the traditional performance indicator - the adjusted Altman Z-score as well as one of the recent indicators - the Bex Index.

\subsection{Business Excellence Model}

The Business Excellence Model, otherwise known as the BEX index, represents models based on balance indicators developed for the capital market in Croatia. The model enables a fast and simple evaluation of a company's solvency [7].

The BEX index is calculated using the following formula:

$$
\mathrm{BEX}=0.388 \mathrm{ex}_{1}+0.579 \mathrm{ex}_{2}+0.153 \mathrm{ex}_{3}+0.316 \mathrm{ex}_{4},
$$

where,

Ex $_{1}$ - Earnings before Interest and Taxes/Total Assets

$\mathrm{Ex}_{2}-$ Net Profit /Equity Capital x capital price

$\mathrm{Ex}_{3}-$ Net Working Capital /Total Assets

$\mathrm{Ex}_{4}-5 \mathrm{x}($ Net Profit + Depreciation + Amortization $) /$ Total Debt

and can be extended as BEX $=0.388 \mathrm{x}$ EBIT / Total Assets $+0.579 \mathrm{x}$ Net Operating Profit /Equity Capital x capital price $+0.153 \times$ Net Working Capital /Total Assets + $0.316 \times 5 \times$ (Net Profit +Depreciation + Amortization) /Total Debt

Companies with a BEX greater than 6.01 are classified as world class companies, excellent is between 4.01 and 6.00 and a candidate for world class, between $2.01-4.00$ is very good, $1.01-2.00$ is good, $0.00-1.00$ lies in a borderline area, and companies with the BEX index lower than 0 as companies facing a jeopardized existence.

The original formula was changed in 2008, when [7] had its parameter Ex 2 - net profit replaced with net operating profit. Further adjustment was made providing correction for a avoiding revaluation effect in 2011. [8] BEXR $=0.388$ $\mathrm{x}(\mathrm{EBIT}+\mathrm{Rp}) /($ Total Assets $-\mathrm{Rr}-\mathrm{Dt})+0.579 \mathrm{x}$ (Net Operating Profit + RAp) / (Equity Capital - Rr) x capital price +0.153 x Net Working Capital / 
$($ Total Assets - Rr - Dt) + 0.316 x 5 x (Net Profit +Depreciation + Amortization) / (Total Debt - Dt)

where,

$\mathrm{Rp}$ - revaluation reserves transformed into retained earnings

$\mathrm{Rr}$ - revaluation reserves

Dt - deferred taxes on profit

RAp - revaluation reserves from depreciation transformed into retained earnings

\subsection{Adjusted Altman Z-score}

The Altman Z-score is a statistical tool used to measure the likelihood of a company going bankrupt. Although Altman devised the Z-score in the 1960s, the notion of trying to predict which companies would fail was far from new at that time. However, Altman added a statistical technique called multivariate analysis to the mix of traditional ratio-analysis techniques, and this allowed him to consider not only the effects of several ratios on the "predictiveness" of his bankruptcy model, but to consider how those ratios affected each their usefulness in the model. The standard Z-score determines how likely a company is to fail. The formula does this by evaluating seven simple pieces of data, all of which should be available in the company's public disclosure.

The formula for the Z-score (which incorporates those seven simple pieces of data) is:

Z-score $=([$ Working Capital $/$ Total Assets $] \underline{x} 1.2)+([$ Retained Earnings $/$ Total Assets $]$ x 1.4 $)+([$ Operating Earnings / Total Assets $]$ x 3.3 $)+([$ Market Capitalization / Total Liabilities $] \times$ 0.6) $+([$ Sales / Total Assets $] \times 1.0)$ [1].

In general, the lower the score, the higher the chance of bankruptcy. For example, a Z-score above 3.0 indicates financial soundness; below 1.8 suggests a high likelihood of bankruptcy. In 2002, Altman advocated a revised Z-score formula for private companies.

In this paper, the Altman performance excellence methodology adjusted for nonmanufacturing firms has been applied. Altman originally developed the Zscore for manufacturers, primarily because those were the companies in his original sample. However, the emergence of large, public service companies prompted him to develop a second Z-score model for non-manufacturing companies.

The formula is essentially the same as before; it just excludes the last component (sales/total assets) given that Altman wanted to minimize the effects of manufacturing-intensive asset turnover. 
Z-score estimated for non-manufacturers \& emerging markets

$\mathrm{X}_{1}=($ Current Assets - Current Liabilities $) /$ Total Assets

$\mathrm{X}_{2}=$ Retained Earnings / Total Assets

$\mathrm{X}_{3}=$ Earnings Before Interest and Taxes / Total Assets

$\mathrm{X}_{4}=$ Market Value of Equity / Total Liabilities

Z-score bankruptcy model:

$$
\mathrm{Z}=6.56 \mathrm{X}_{1}+3.26 \mathrm{X}_{2}+6.72 \mathrm{X}_{3}+1.05 \mathrm{X}_{4}
$$

Zones of discriminations:

$\mathrm{Z}>2.9$-"Safe" Zone

$1.22<\mathrm{Z}<2.9$-"Grey" Zone

$\mathrm{Z}<1.22$-"Distress" Zone [2].

\section{Results}

Analyzed results have been passed by a set of carefully selected shipping companies with hundreds of them operating in competition on the international bulk cargo market. Specifically, the authors have established the following minimum criteria for selecting a representative set of bulk carries in the statistical sample.

The first requirement is that maritime companies should possess a similar structure of their fleet and further, similar fleet structure dimensions.

The second requirement is that shipping companies should have the biggest share of ships for transporting bulk cargo, i.e. the shipping companies must have at least seventy percent of bulk carriers in their fleet. Hence, from the perspective of European shipping companies, Atlantska plovidba d.d. and Euroseas Ltd have been chosen in the representative sample, as well as the American company DryShips Inc. and two Asian shipping companies Courage Marine Group Limited and Malaysian Bulk Carriers Berhard Group (MBC Group). For each shipping company from the representative sample, the correlation between total annual revenue and BDI has been estimated.

The general conclusion is that there is a strong correlation between these two variables. As for the total annual shipping company revenue throughout the analyzed period, quarterly revenue movement has also been analyzed and correlated with the average BDI values. 


\begin{tabular}{|c|c|c|c|}
\hline Year & $\begin{array}{c}\text { Total annual revenue of } \\
\text { Atlantska plovidba d.d. } \\
(\mathrm{u} 000 \mathrm{kn})\end{array}$ & $\begin{array}{c}\text { Total annual revenue of } \\
\text { Courage Marine Group limited } \\
(\mathrm{u} \mathrm{000} \mathrm{kn})\end{array}$ & $\begin{array}{c}\text { Average BDI } \\
\text { values }\end{array}$ \\
\hline 2005 & 330591 & 1228065 & 3383 \\
\hline 2006 & 278322 & 1159486 & 3188 \\
\hline 2007 & 603823 & 1365863 & 7096 \\
\hline 2008 & 404941 & 1453033 & 3647 \\
\hline 2009 & 256224 & 832263 & 2622 \\
\hline 2010 & 409722 & 927211 & 2762 \\
\hline 2011 & 342345 & 592582 & 1548 \\
\hline 2012 & 287585 & 515024 & 923 \\
\hline 2013 & 102963 & 589835 & 1033 \\
\hline
\end{tabular}

Table 1: Total annual revenues for chosen shipping companies and average BDI values from 2005 to 2013. Source: Financial reports and authors construction

Given the nature of this article, presenting all the processed data and results is not possible. However, the most important outcome is that these results also confirm the basic conclusion, which is a strong positive and statistically significant correlation between the average quarterly BDI value and the average quarterly revenue of each shipping company for the period 20052013. By estimating and analyzing the link between performance excellence and BDI for each shipping company from a representative sample and for each year of the research period, the performance excellence has also been estimated using two indicators. One of them is the traditional indicator of business performance, i.e. the adjusted Altman Z-score, and the second is the recent Bex Index, both explained in the previous section.

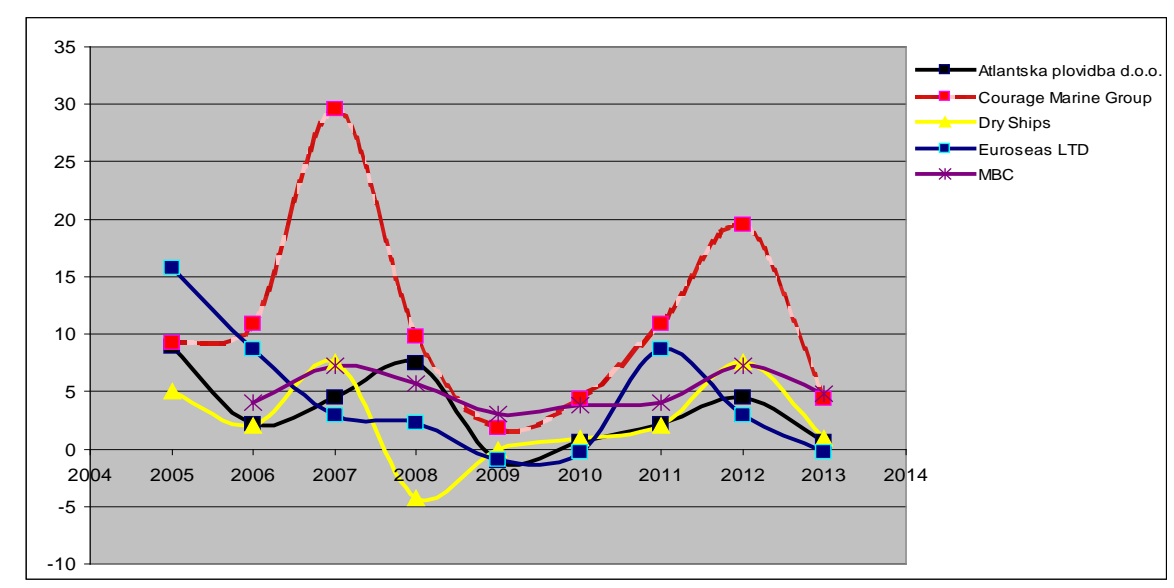

Figure 4: Trend of Bex Index values from 2005 to 2013 for shipping companies from the representative sample. Source: Financial reports and authors construction 
In analyzing Figure 4, Figure 5 and Table 1, spotting the same direction and intensity of movement of both performance indicators and average annual BDI values for all the observed shipping companies throughout the research period is simple. As a contribution to the integrity of the methodological procedure, correlation analysis has been carried out using an estimation of coefficients. Pearson's linear correlation coefficients between the average, annual BDI values and the calculated performance excellence indicators values have been estimated.

For all shipping companies from the representative sample for the entire research period from 2005-2013, the estimated values of the Pearson's linear correlation coefficients vary from 0.81 to 0.88 . Once again, this confirms the general conclusion of a strong positive correlation between average annual BDI values and the calculated performance excellence indicators. Specifically, all the mentioned correlations have Pearson coefficient values exceeding 0.8, and they are statistically significant at a $5 \%$ level.

Over the last year, daily correlation has shown the following: the BDI index exhibits a significant positive correlation with changes in share prices of companies listed in the sector of the marine transportation market. Very low shipping freights are supported by the fact that the world economy has been in a crisis over the last fourth years. According to some announcements, the recovery of the world cargo market could occur within the next two years, but there are those who argue that the current poor state could last much longer, and this is the main reason for a low valuation of the companies listed in the marine transportation sector.

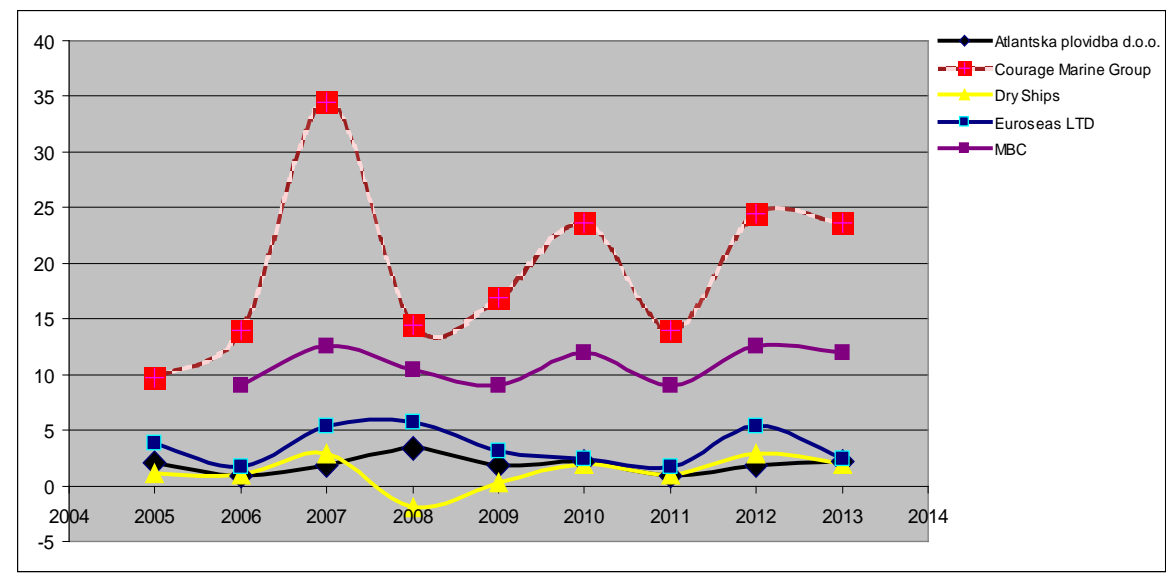

Figure 5: Trends for values of the adjusted Altman Z-score from 2005 to 2013 for shipping companies from the representative sample. Source: Financial reports and authors construction 


\section{Conclusion}

This paper deals with a particular approach to analysing the relationship between BDI as the main indicator of the cyclical nature of the maritime market and the performance excellence of the representative shipping companies. The entire methodological procedure has been carried out using a real database related to shipping companies chosen for the case study. Specifically chosen were European, Asian and American shipping companies that possess at least seventy percent of the ships in their fleet for transporting bulk cargo, otherwise known as called bulk carriers, and those that have a similar fleet structure dimensions.

For the period from 1985 to 2013, the performance excellence of maritime companies has been estimated by two indicators. One of them is a traditional indicator of business performance called the adjusted Altman Z-score and the second is the recent Bex Index.

For the same research period, as the most comprehensive indicator of the global demand for commodities and raw materials, the BDI has been analyzed as a supply and demand signal on the stock market. It is commonly accepted that the BDI is just such a signal in a no crisis period, and the results of this paper confirm that the BDI, acting as a signal, also responds promptly to the effects of a crisis.

The general conclusion of this paper is that there is a strong positive and statistically significant correlation between average annual BDI values and the calculated performance excellence indicators. Moreover, in the case of a high correlation between short-term (quarterly) average BDI values and the business excellence results of companies, BDI values signal the opportunity of buying or selling certain shares. This signal is even more important as it occurs before the quarterly accounting reports of maritime companies.

During the observed time period, shipping companies from the representative sample had a different strategy in hedging BDI volatility. A possible area of future research could be discovering whether shipping companies with similar performance excellence indicators implement a similar strategy for hedging BDI volatility.

\section{References}

[1] Altman, E. I. (1968). Financial ratios discriminate analysis, and the prediction of corporate bankruptcy. Journal of Finance, 23(4), 589-609. doi:10.1111/j.15406261.1968.tb00843.x.

[2] Altman, E. I., (2000). Predicting financial distress of companies: Revisiting the Zscore and Zeta models". Journal of Banking and Finance, July, 25-27.

[3] Atlantska plovidba d.d., Dubrovnik, http://www.atlant.hr/ [Accessed on February 13, 2014]. 
[4] Bakshi, G., Panayotov, G. and Skoulakis, G. (2011). Improving the predictability of real economic activity and asset returns with forward variances inferred from option portfolios. Journal of Financial Economics, 100(3), 475-495. doi:10.1016/j.jfineco.2011.01.002.

[5] Baltic Exchange Shipping Market Information Derivative Reports (1985-2013), http://www.balticexchange.com/market-information/reports/ [Accessed on January 12, 2014].

[6] Barty-King, H. (1994). The Baltic Story - Baltick Coffee House to Baltic Exchange. Quillen Press, London, 1774-1994.

[7] Belak, V. and Aljinović Barać, Ž. (2007). Business excellence (Bex) indeks - za procjenu poslovne izvrsnosti tvrtki na tržištu kapitala u Republici Hrvatskoj (Business excellence (Bex) index - for the assessment of business excellence of companies on the capital market in Croatia). Računovodstvo, revizija i financije (Journal of Accounting, Auditing and Finance), 10, 15-25.

[8] Belak, V. (2011). Poslovna forenzika i forenzičko računovodstvo - Borba protiv prijevare (Business Forensics and Forensic Accounting - The Fight Against Fraud). Zagreb: Belak Excellens d.o.o.

[9] Binsbergen, J. and Koijen, R., (2010). Predictive regressions: A present-value approach. Journal of Finance, 65(4), 1439-1471. doi:10.1111/j.1540-6261.2010.01575.x.

[10] Dangl, T. and Halling, M., (2012). Predictive regressions with time-varying coefficients. Journal of Financial Economics 106, 157-181. doi:10.1016/j.jfineco.2012.04.003.

[11] Faqin, L. and Nicholas Cheng Siang, S. (2013). Trade, income and the Baltic Dry Index. European Economic Review, 59, 1-18. doi:10.1016/j.euroecorev.2012.12.004.

[12] Hasabullah, A. and Zulkarnain, M. (2009). Financial ratios, discriminate analysis and the prediction of corporate distress. Journal of Money, Investment and Banking ISSN 1450-288X Issue 11 (2009), http://Www.eurojournals.com/JMIB.htm. [Accessed on December 13, 2013].

[13] Hassan, M. K., B. and Sanchez, J. S. Yu. (2011). Financial development and economic growth new evidence from panel data. Quarterly Review of Economics and Finance, 51, 88-104. doi:10.1016/j.qref.2010.09.001.

[14] Hong, H. and Yogo, M. (2012). What does futures market interest tell us about the macroeconomy and asset prices. Journal of Financial Economics, 105(3), 473-490. doi:10.1016/j.jfineco.2012.04.005.

[15] Rodrigue, J. P., Comtois, C. and Slack, B. (2013). The Geography of Transport Systems. New York, 3rd edition, Routledge.

[16] Teplý, P. (2010). The Truth about the 2008-2009 Crisis: A Hard Lesson for the Global Markets. Saarbrücken: VDM Verlag.

[17] Learning markets. Understanding the Baltic Dry Index, http://www. learningmarkets.com/understanding-the-baltic-dry-index/ [Accessed on December 13, 2013].

[18] Precision trading systems. Using the Baltic Dry Index as a trading tool for directional market confirmation, http://www.precisiontradingsystems.com/Baltic_dry_index.htm [Accessed on December 13, 2013].

[19] Zero Hedge, http://www.bullfax.com/?q=node-baltic-dry-index-collapses-18month-lows-worst-july-198 [Accessed on August 12, 2014]. 